\title{
SURFACE AND BEDROCK TOPOGRAPHY OF ICE CAPS IN ICELAND, MAPPED BY RADIO ECHO-SOUNDING
}

\author{
by
}

Helgi Björnsson

(Science Institute, University of Iceland, Dunhagi 3, 107 Reykjavík, Iceland)

\section{ABSTRACT}

Since 1977, large areas on western Vatnajökull have been surveyed by ground-based, radio echo-sounding and the whole ice cap, Hofsjökull, was surveyed in 1983. Detailed maps of the glacier-surface elevation and the sub-ice bedrock have been compiled. The instrumentation includes a 2-5 MHz, mono-pulse echo-sounder, for continuous profiling. a satellite geoceiver and Loran-C equipment, for navigation, and a precision pressure altimeter. The maps of western Vatnajökull cover about $1500 \mathrm{~km}^{2}$ and are compiled from $1500 \mathrm{~km}$-long sounding lines, which yielded about 50000 data points for ice thickness and 20000 points for ice-surface elevation. The maps of Hofsjökull cover $923 \mathrm{~km}^{2}$, the sounding lines were $1350 \mathrm{~km}$ long; 42000 points were used for determining ice thickness and 30000 for surface elevation. The maps obtained from these data are the first ones of the ice caps with surface elevation of known accuracy. The bedrock map of western Vatnajökull shows details of volcanic ridges and subglacial valleys, running north-east to south-west, as well as the central, volcanic complexes, Hamarinn, Bárdarbunga, and Grimsvötn and the related fissure swarms. The map of Hofsjökull reveals a large volcanic complex, with a $650 \mathrm{~m}$ deep caldera. The landforms in southern Hofsjökull are predominantly aligned from north to south, but those in the northern ice cap run north by $25^{\circ}$ east.

\section{INTRODUCTION}

The paper describes detailed mapping of the ice surface and bedrock topography of western Vatnajökull and the whole ice cap, Hofsjökull, in central Iceland (Fig.1). Both ice caps are situated within the active volcanic zone and cover unexplored landforms, significant geological structures, and volcanic features. Further, some of the largest rivers in Iceland originate at these ice caps.

The first maps that outline, with some accuracy, the extent of ice caps in Iceland were surveyed by the Danish Geodetic Institute, in the period 1904 to 1938, and published on a scale of 1:100000 (Nørlund 1944). On these maps, however, the indicated ice-surface elevation was not based on surveying, except along the edge of the glaciers. The contour lines were drawn with the help of oblique aerial photographs and show, according to Nørlund (1944), the form of the ice surface, rather than its elevation. The

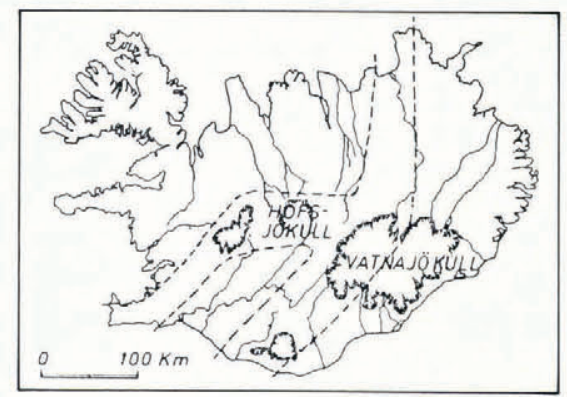

Fig.1. The ice caps of Iceland and the location of the active volcanic zones. maps of western Vatnajökull, as well as Hofsjökull, were surveyed in 1937-1938 and the oblique aerial photographs date from 1938. The position of the glacier edge was later revised by air photographs from 1961 (see Fig.5).

The next maps of the glaciers were compiled by the U.S. Army Map Service, on a scale of 1:50 000, on the basis of air photographs from 1945-46 and the triangulation system previously surveyed by the Danish Geodetic Institute. The ice-surface contours, in the marginal areas of the ice caps (some few $\mathrm{km}$ up from the edge), were compiled from the air photographs, but, higher up, the contours are identical with those of the Danish Geodetic Survey maps. A recent test of the reliability of the elevation contours on these maps (outside the ice caps, of course) indicates that they are generally accurate to $\pm 10 \mathrm{~m}$, but, in some places, they prove to be wrong by up to $100 \mathrm{~m}$ (Sigmundur Freysteinsson and Örn Arnar Ingólfsson, personal communication 1985). In addition to these two sets of maps, ice elevation has repeatedly been geodetically levelled on two profiles on western Vatnajökull (Tungnaárjökull) (see Freysteinsson 1984) and from Grimsvötn north-east, towards Kverkfjöll. Further, Landsat images of Vatnajökull (see Fig.3) show the extent of the ice cap and surface forms which reflect sub-ice features (porarinsson et al. 1973). The same applies to Hofsjökull (Fig.4), which covers prominent, buried, volcanic structures (see e.g. Sæmundsson 1979).

Exploration of the ice thickness of Vatnajökull and the sub-ice topography started in 1951, when a French-Icelandic expedition carried out seismic soundings at 33 points, spread over the ice cap (Holtzscherer 1954). On the basis of these soundings, Eythórsson $(1951,1952)$ presented a preliminary map of the bedrock beneath Vatnajökull. This map shows the central ice masses resting on a highland plateau, at $700-800 \mathrm{~m}$ altitude, and only a few peaks rising above the $1000 \mathrm{~m}$ elevation, which marks the present level of the firn line in the southern part of Vatnajökull. In 1955, a second French-Icelandic expedition continued the seismic work on Vatnajökull (Sigurdsson 1970) and on Myrdalsjökull (Rist 1976).

The next step in the exploration of the ice depths was taken on Vatnajökull by gravity surveying. In 1960 and 1961, the average ice thickness was estimated in the Grimsvötn area and along a profile from Grimsvötn to Kverkfjöll (Pálmason 1964). Two profiles were later surveyed at Tungaárjökull (Sigurdsson 1970) and Thorbergsson (unpublished data) made gravity measurements on several points on Vatnajökull, in 1971. Björnsson (1974) summarized all the available data. No observations were available on the bedrock topography of glaciers other than Vatnajökull and Mýrdalsjökull.

Since 1977, the Science Institute of the University of Iceland has made radio echo-soundings of ice depths. Continuous ice thickness profiling has been carried out by a series of oversnow traverses on large areas of the ice caps Vatnajökull, Hofsjökull, and Mýrdalsjökull, as well as on some valley glaciers (Björnsson 1977, 1981, Björnsson et. al. 1977, Sverrisson et. al. 1980, and Björnsson (various internal reports)). The total length of the sounding lines is about $4000 \mathrm{~km}$ so far. Maps of the glacier surface and the sub-ice bedrock have been compiled. Since 1980, the main work has been funded by the Iceland Power Company. 


\section{RADIO ECHO-SOUNDING SURVEYING}

Instrumentation for the radio echo-sounding survey includes an echo-sounder, a satellite geoceiver and Loran-C equipment for navigation, and a precision, pressure altimeter.

\section{The echo-sounder}

The radio echo-sounder is a mono-pulse system, designed by the Science Institute (Sverrisson and others 1980). Pulses of $0.2 \mu \mathrm{s}$ duration are transmitted into a $30 \mathrm{~m}$-long, resistively-loaded, dipole antenna, at the repetition rate of $1 \mathrm{kHz}$. The reflected signal is picked up by an identical antenna and fed into a receiver, which has a 2-5 $\mathrm{MHz}$ band-pass filter. The transmitter and the receiver are placed on sledges at the centre of the antennae and towed on a line along the glacier surface. The intensity modulation ( $\mathrm{Z}$-scope display) of the received signal is recorded photographically on a $35 \mathrm{~mm}$ camera, which is held open while the base of the oscilloscope is scanning the screen. The speed of the scanning beam is proportional to the angular velocity of a bicycle wheel, which is mounted on the receiver sledge. Fig. 2 shows a typical profile from

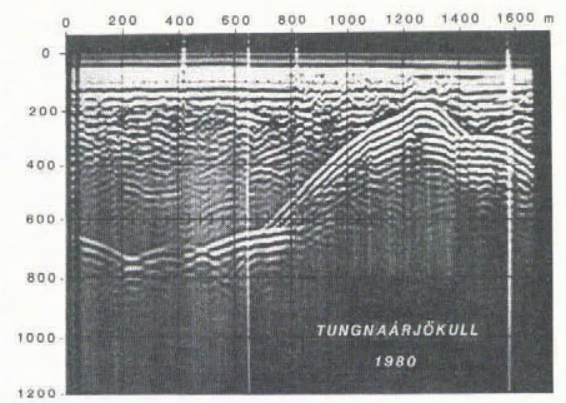

Fig.2. A typical radio echo-sounding profile from Vatnajökull.

the echo-sounder, with the two-way, travel time of the electromagnetic wave on the $\mathrm{Y}$-direction and the traversed, oversnow distance on the $\mathrm{X}$-axis. For ice thickness of more than $700 \mathrm{~m}, 60 \mathrm{~m}$-long antennae may have to be used to get a good bedrock return.

Navigation

During the first two years of radio echo-sounding, navigation on traverses across the ice was only done by means of compass bearing and the distance derived from the bicycle wheel of the echo-sounder. Markers for position were put on the film record of the sounder. The accuracy in position of these sounding lines is assumed to have been $\pm 200 \mathrm{~m}$. Since 1982, however, Loran-C has been used for navigation on all traverses on the ice caps and, from 1983, the latitude and longitude obtained from Loran-C (in WGS 66 coordinates) has been recorded on a magnetic tape at $100 \mathrm{~m}$ intervals, along all sounding lines. The corrections due to using the Loran on the ground have proved to be systematic within the surveying area and of the order of some hundred metres. The correction has been determined by satellite navigation in a few points in the area. The final position of the sounding lines is expected to be accurate to better than $\pm 50 \mathrm{~m}$.

For detailed mapping, an orthogonal grid of sounding lines has been placed on the glaciers, usually with a separation of $500 \mathrm{~m}$ to $1000 \mathrm{~m}$ between the lines (see Fig.5). Up to the year 1982, the grid was set out by geodetic surveying and all data for position, ice thickness, and ice elevation referred to the coordinate system of this grid. The geographical position of the grid was later fixed by satellite navigation. The position of the sounding line is considered to be accurate to $\pm 30 \mathrm{~m}$. Since 1983, grids have not been geodetically surveyed, but the position of the sounding lines has been logged by Loran-C (to $\pm 50 \mathrm{~m}$ ), (Fig.8). This has speeded up the sounding work.

\section{Determination of ice-surface elevation}

The ice-surface elevation was derived by precision, barometric altimetry. Up to the year 1981, the barometer was read manually at $100-300 \mathrm{~m}$ intervals along the sounding lines and the position marked on the film record of the echo-sounder. Since 1982, a barometric altimeter has recorded on magnetic tape every $50 \mathrm{~m}$ along the sounding lines. Corrections are made for temperature effects and a barometer records variations in pressure with time at the base camp. All elevations are related to the altitude of the neighbouring mountain peaks. The absolute accuracy is considered to be $\pm 15 \mathrm{~m}$ on the sounding lines and the relative elevations are estimated at $\pm 10 \mathrm{~m}$. The difference in surface elevations at crossing points was less than $5 \mathrm{~m}$ in all points at Hofsjökull, but about $10-15 \mathrm{~m}$ on western Vatnajökull. This is caused by calibration errors of the altimeter, as well as uncertainty in the location of the crossing points. Occasionally, the altitude on the sounding lines has been geodetically levelled.

\section{DATA REDUCTION}

The photographic records of the return echo have been digitized, with an interval of about $30 \mathrm{~m}$ in oversnow distance between points. The geographical position of these echo points is obtained by interpolation between the points where position was recorded on the sounding line. The vertical depth of ice was obtained from the digitized, photographic records by general, one-dimension, inversion techniques, as described by Harrison (1970). The result is a final, geographical position of the points of reduced ice thickness on the sounding line. A constant velocity of electromagnetic waves in ice of $169 \mathrm{~m} / \mu \mathrm{s}$ was used. A correction, due to higher velocity in the surface firn layer, was neglected, as its maximum thickness is about $20-30 \mathrm{~m}$. About $80 \%$ of all crossing points show a difference in ice thickness of less than $20 \mathrm{~m}$. In a complex topography, sounding lines perpendicular to the bedrock slopes were given the highest priority and the deepest reflection selected, after a manual inversion. The accuracy for the ice thickness is considered to be $\pm 15 \mathrm{~m}$, or $2 \%$, whichever is greater.

The bedrock elevation was obtained as the difference between the ice-surface altitude and the ice thickness. The absolute bedrock elevation is estimated to $\pm 30 \mathrm{~m}$.

\section{MAP COMPILATION}

The maps of the bedrock and surface topography were compiled, using data from the sounding lines and elevations from maps outside the glacier, as well as data from recent surveying by the National Energy Authority (Gunnar Thorbergsson, personal communication). The outline of the edge of the glaciers was digitized from Landsat images and recent glacier variations were included. The reduced data of ice-surface and bedrock elevations were put into a grid of conformal, conical, Lambert coordinates. The maps were drawn on the basis of the reduced data and values obtained by interpolation through them. The first interpolation routine assigned values for each $100 \mathrm{~m}$ distance along the sounding lines, placed a spline-curve across these points and derived values for each grid, of $100 \times 100 \mathrm{~m}$ square, of the surveying area. Further, surface-trend analysis of the computer program, Surface II (Simpson 1978), has been used for gridding and producing contour maps, which are considered fairly reliable for our set of data. The final maps, however, have been drawn by hand, after checking the interpolation. The reduced data and the data obtained by interpolation are stored in a data-base for use as a digital map.

\section{MAPS OF WESTERN VATNAJÖKULL}

In 1980 , the ice-surface elevation and bedrock were mapped in detail on the outlets, Tungnaárjökull and Sylgjujökull and, in 1982, on Köldukvislarjökull (the outlets are named after the rivers). Outside these outlets, the map is drawn from data obtained in various traverses since 1977. Fig.5 shows the grid of all the sounding lines placed on the Danish Geodetic Survey map of western Vatnajökull. Points located with satellite navigation are marked as dots on the map.

The maps of Tungnaárjökull and Sylgjujökull cover an area of $350 \mathrm{~km}^{2}$. The total length of the sounding lines was about $600 \mathrm{~km}$. The main 25 lines were placed parallel, $1 \mathrm{~km}$ apart, perpendicular to the ridges reflected north-east to south-west on the Landsat image (Fig.3), thus simplifying 


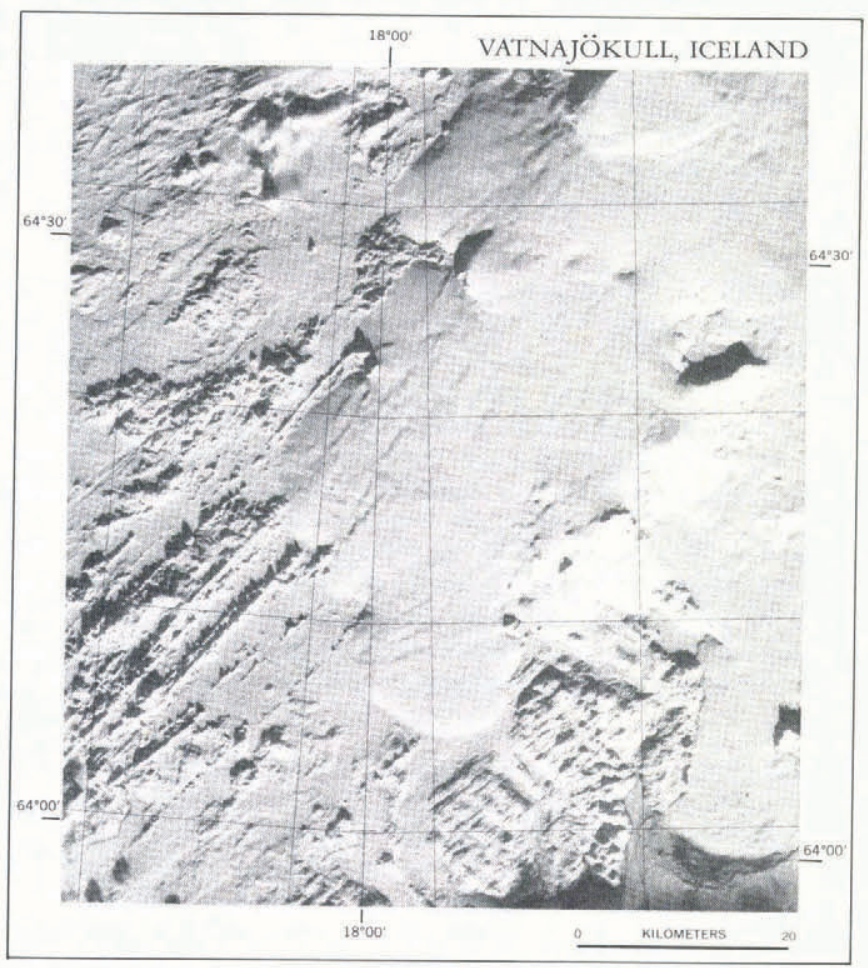

Fig.3. A Landsat image of Vatnajökull (31 January 1973). (Copies from a map, published by the U.S. Geological Survey, in cooperation with the Iceland Geodetic Institute and the Icelandic National Research Council). the migration from reflection to true ice depths. Seven $25 \mathrm{~km}$-long lines run north-east to south-west. The ice thickness was calculated at about 15000 echo-sounding points. The ice-surface contour map is based on points at 200-300 m intervals, along the sounding lines; about 2000 points altogether.

The maps of Köldukvíslarjökull cover an area of $550 \mathrm{~km}^{2}$. The total length of sounding lines was $560 \mathrm{~km}$

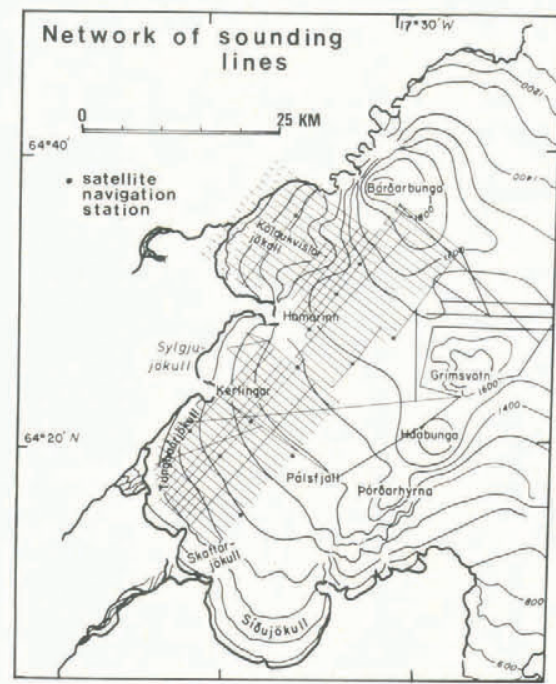

Fig.5. Radio echo-sounding lines on western Vatnajökull, plotted on the map surveyed by the Danish Geodetic Institute in 1937-38.

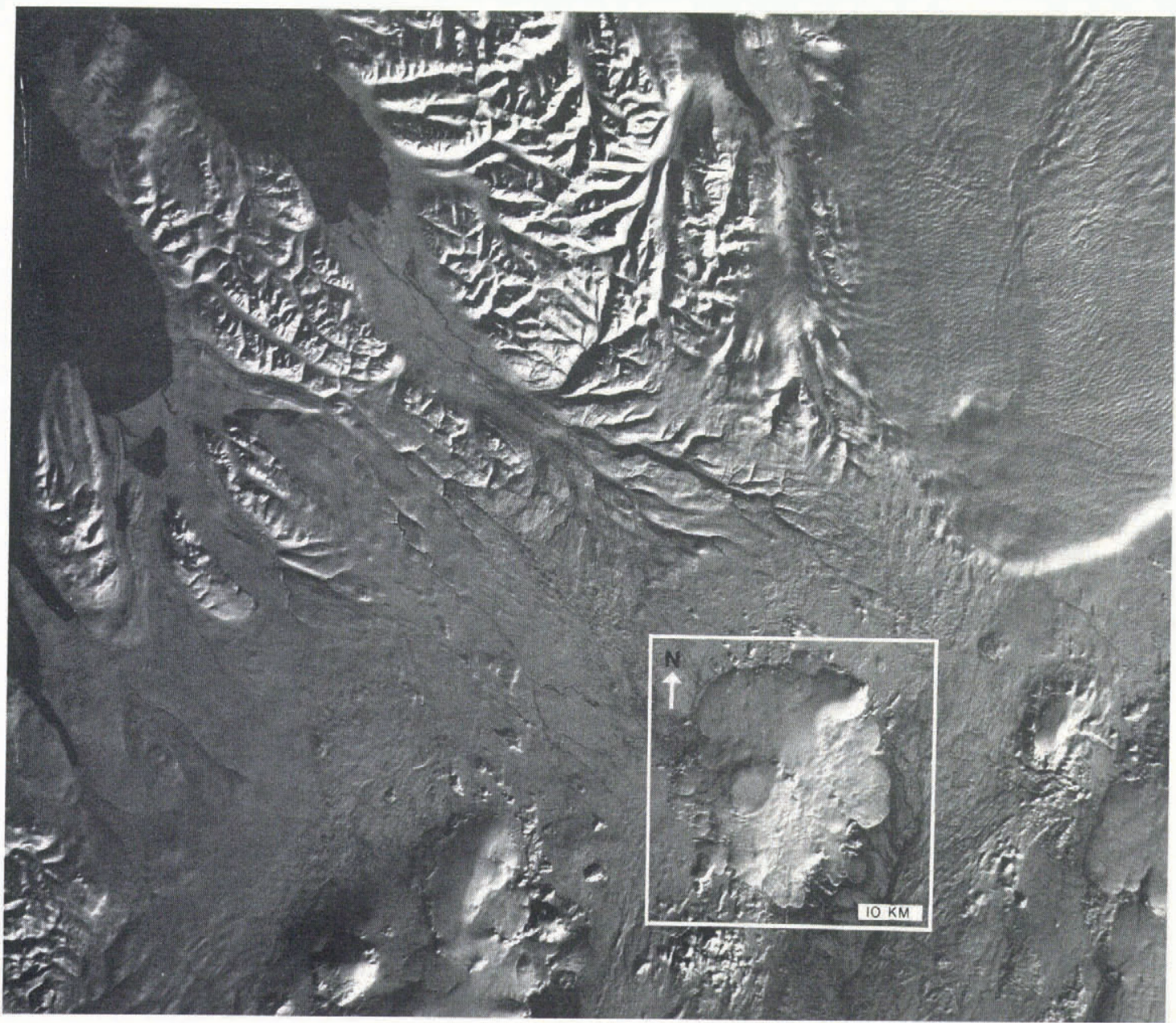

Fig.4. A Landsat image of Hofsjökull (S 237014 C7, 20th October 1980, obtained from the Iceland Geodetic Survey). 


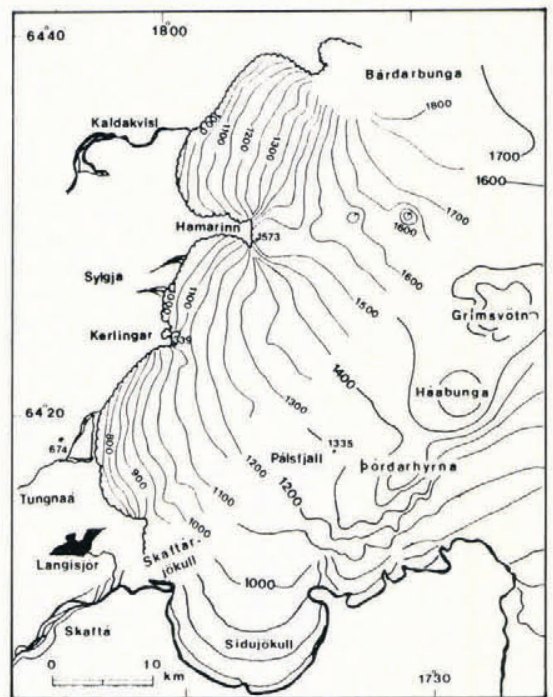

Fig.6. A map of ice-surface contours of western Vatnajökull. The easternmost part of the map shows the contours from the map of the Danish Geodetic Institute, see Fig.5. and the number of data points for ice thickness about 17000 and 10000 for the ice-surface elevation. Bedrock return was obtained over the whole area, but was rather faint in some places with ice thickness of $800-900 \mathrm{~m}$ (between Bárdarbunga and Grímsvötn). This may partly be caused by internal ash layers.

\section{GLACIER SURFACE MAPS}

Fig.6 shows a map, with $50 \mathrm{~m}$ contour intervals, of western Vatnajökull. This is the first map of the glacier with known accuracy and shows surface forms created by the flow of ice, thus reflecting the bedrock structures. Further, the map shows, in detail, ice cauldrons, north-west of Grimsvötn, that are created by subglacial, geothermal activity and drain water, in jökulhlaups, to the river Skaftá (see e.g. Björnsson 1977). Comparison with the 1938 map of the Danish Geodetic Institute (Fig.5) shows the most striking difference in the northern part above $1500 \mathrm{~m}$ elevation. In the area between Grimsvötn and Bárdarbunga, the old maps have underestimated elevations by $50-100 \mathrm{~m}$.

\section{BEDROCK TERRAIN: GEOLOGICAL STRUCTURES}

Fig.7 shows a map, with $50 \mathrm{~m}$ contours, of the bedrock of western Vatnajökull. The bedrock elevation is, on the whole, lower in the southern than in the northern part of western Vatnajökull. On Sidujökull, Skaftárjökull

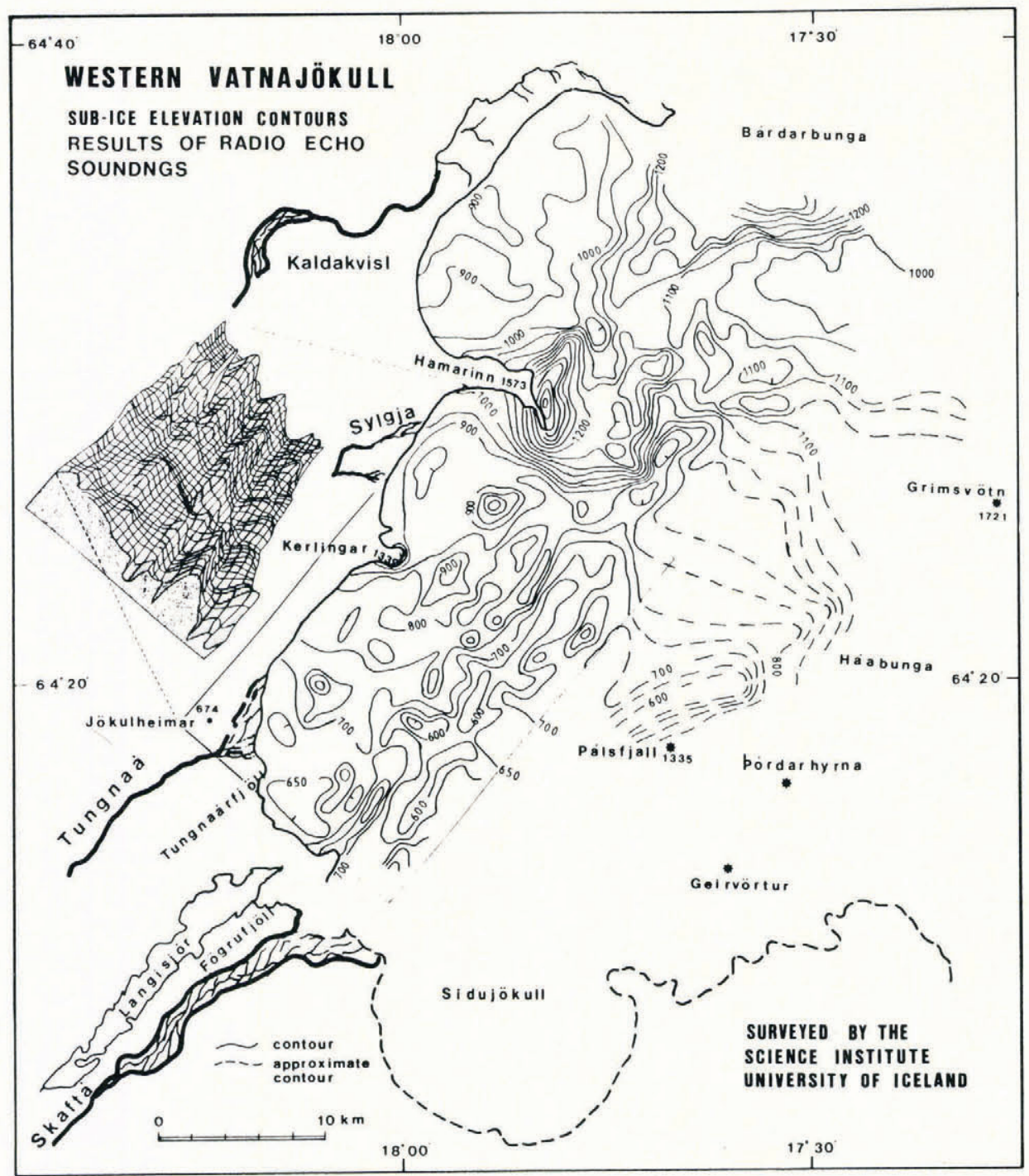

Fig.7. A map of sub-ice contours of western Vatnajökull. A three-dimensional, perspective plot of Tungnaárjökull is added. 
and Tungaárjökull (see Fig.6 for place names) the bed is lower than $850 \mathrm{~m}$, but is above that height everywhere in the northern area. In the south, the topography is dominated by long linear ridges, north-east to south-west, which are, presumably, volcanic fissures, hyaloclastic ridges, and crater rows. In the north-eastern area, the landscape is dominated by the central volcano complexes, Hamarinn, Bárdarbunga, and Grimsvötn and mountain ridges running out from them. In their analysis of the Landsat image of Vatnajökull of 31 January 1973, Thorarinsson and others (1973) pointed out that a feature, aligned north-west to south-east $\left(\mathrm{N} .35^{\circ} \mathrm{W}\right)$ from Thordarhyrna towards Hamarinn, separates these two, markedly-different, tectonic regimes.

The main mountain ridge in the southern area runs north-east from Langisjor and Fögrufjöll and all the way up to Hamarinn. Isolated mountains, $850-1000 \mathrm{~m}$ high, are seen on both sides of the ridge, east of Kerlingar. This ridge is clearly reflected on the glacier surface and separates the outlets Tungnaárjökull and Skaftárjökull. East of it, the bed declines toward the main part of the ice cap, where erosion has taken place for thousands of years and tectonic lineaments may have become obscured. There, a $30 \mathrm{~km}$-long valley, bounded by the ridge, reaches all the way up to the south-eastern slopes of Hamarinn. Another banch of this valley seems to stretch north of the nunatak, Pálsf jall, and eastward to the slopes of Háabunga. The bottom of the subglacial valley is, in places, below $600 \mathrm{~m}$ and locally down to $550 \mathrm{~m}$. Thus, in large areas, the bedrock is lower than in front of the glacier outlets. On Tungnaárjökull, to the west of the main ridge, the bed is about $100 \mathrm{~m}$ higher than east of it. Tungnaárjökull has eroded its bed for a shorter time than has the older, main ice cap.

Three central volcanos have built up mountains by volcanic eruptions in the northern area. Those are Hamarinn and Bárdarbunga, at the glacier edge, and Grímsvötn, in the interior of the ice cap. Mountain ridges radiate from the volcanoes and, presumably, they show the strike of the related, volcanic, fissure swarms, as mountains tend to build up above the subglacial craters. Hamarinn is a steeply sloped volcano, about $60 \mathrm{~km}^{2}$ in area inside its nearly circular rims, that slope from $1570 \mathrm{~m}$ down to about $1200 \mathrm{~m}$. A slight depression is found inside the rim, suggesting a caldera formation. The main ridge separating Tungnaárjökull and Skaftárjökull, strikes south-east from the southern slopes of Hamarinn. At the glacier edge, this fissure swarm continues south-west, south of Langisjor. Another ridge strikes east from the north-eastern corner of Hamarinn, 1100-1200 m high, but terminates after about $10 \mathrm{~km}$. About $2-3 \mathrm{~km}$ further south and $5 \mathrm{~km}$ east of Hamarinn, another, separate, ridge starts and continues eastward all the way to the northern slopes of Grimsvötn. These ridges have shown much geothermal and volcanic activity in recent years, as well as being one of the most active seismic areas in Iceland. In 1938, a large area north of Grimsvötn subsided, presumably due to volcanic activity that did not reach through the ice. About $3 \mathrm{~km}^{3}$ of melt water drained down into Grímsvötn and causeed a large jökulhlaup (Thorarinsson 1974, Björnsson 1974, 1983, Björnsson and Kristmannsdóttir 1984). In 1955, the easternmost ice cauldron was formed, the central one around 1970 , and, in 1980, the westernmost cauldron could be observed (Björnsson 1977, 1983). The two eastern cauldrons drain water down the valley east of the ridge, which separates the outlets Tungnaárjökull and Skáftarjökull. We note that these cauldrons seem to have no connection, through fissure swarms, with volcanic activity, south-west of Vatnajökull. They are located on a ridge, connecting the central volcanos, Hamarinn and Grimsvötn. The third central volcano, Bárdarbunga, was mapped in detail in 1985. The survey revealed a $700 \mathrm{~m}$ deep caldera, surrounded by mountains that reach $1800 \mathrm{~m}$ and rise from $1000 \mathrm{~m}$ elevation on the southern, as well as the northern slope. South of the volcano, more than $900 \mathrm{~m}$-thick ice flows towards Grimsvötn. A ridge strikes south-west across Köldukvislarjökull, from the south-western slopes of Bárdarbunga, but is separated from Hamarinn by a crater-like depression. The volcano, Bárdarbunga, appears to be the centre of an active volcanic system, with a fissure swarm running $150 \mathrm{~km}$ to the south-west (Sæmundsson, 1979 and Larsen 1984).

\section{MAPS OF HOFSJÖKULL}

In 1983, the ice-surface elevation and the bedrock were mapped in detail on the whole of the ice cap of Hofsjökull. Fig.8 shows the position of all the sounding lines, as recorded on a magnetic tape from Loran-C. Most of them run along the longitudinals, but, when necessary, they were placed perpendicular to the slopes of the buried, subglacial structures reflected on the Landsat image (Fig.4). Points fixed by satellite navigation are marked on the map. The ice cap covers an area of $923 \mathrm{~km}^{2}$. Altogether, data from $1350 \mathrm{~km}$ of sounding lines were used in the compilation of the maps. The ice thickness was calculated at about 42000 echo-sounding points. The ice-surface elevation was calculated at about 30000 points.

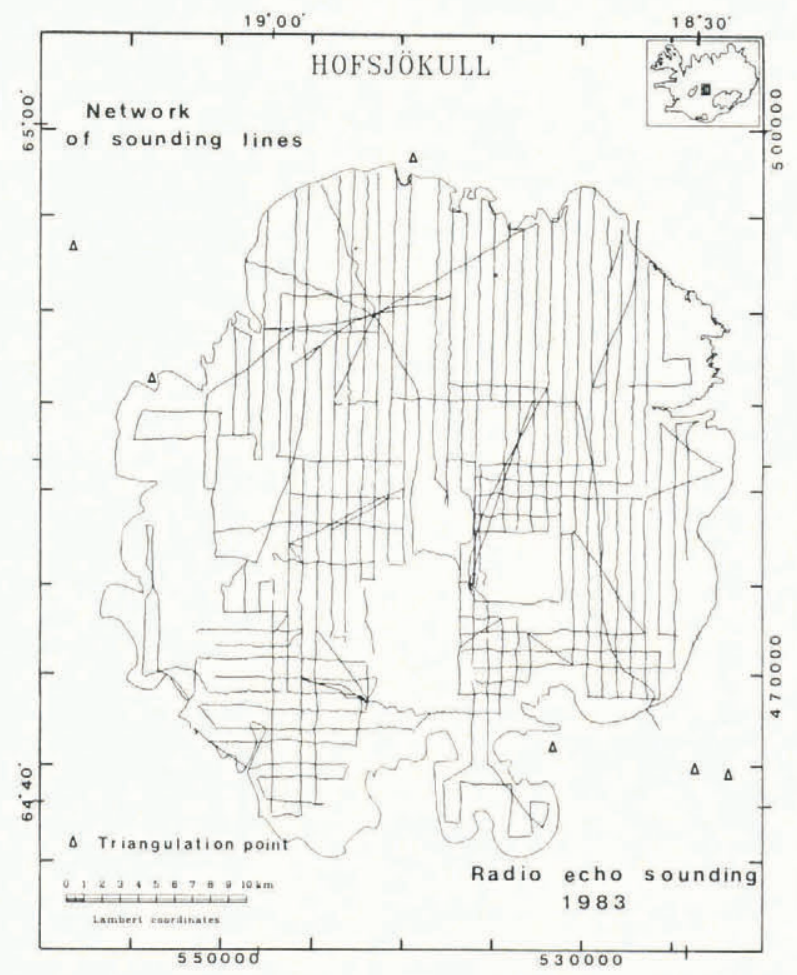

Fig.8. Radio echo-sounding lines on Hofsjökull,

\section{GLACIER SURFACE MAPS}

Fig.9 shows a map, with $50 \mathrm{~m}$ contour intervals, of Hofsjökull. The highest parts of the ice cap form a circular plateau, at about $1800 \mathrm{~m}$ elevation. On earlier maps, the maximum elevation was $1765 \mathrm{~m}$ and all the plateau above $1700 \mathrm{~m}$ has obviously never been correctly mapped. The surface elevations on Thjórsárjökull look fairly similar on both maps, but other areas are lower now than shown on the other maps, as is to be expected. An ice ridge strikes north-east towards Miklafell and ice flows south-east to Thjórsárjökull and Múlajökull, bùt north-west to Sátujökull. The outlets, Blöndujökull and Blágnípujökull, flow westwards and Blautukvislarjökull southwards from the plateau.

\section{BEDROCK TERRAIN AT HOFSJÖKULL}

Fig.10 shows a map, with $50 \mathrm{~m}$ contours, of the bedrock of Hofsjökull. The most prominent landform beneath Hofsjökull is a large, circular volcano, with a $250 \mathrm{~km}^{2}$ base, at $1000 \mathrm{~m}$ elevation. The mountain rises up to rims at $1500-1600 \mathrm{~m}$, surrounding a $600 \mathrm{~m}$ deep caldera. The bottom of the caldera is at about $980 \mathrm{~m}$, which is the same as along most of the edge of the ice cap. To the east, the rims are crowned by the Hasteinar nunataks, made of rhyolite, which indicates that they were formed when the mountain was not covered by ice (see Fig.9 for place names). A breach in the caldera rim, at $1250 \mathrm{~m}$, is facing west. The maximum ice thickness on Hofsjökull is found in the caldera, about $750 \mathrm{~m}$. Fig.11 shows the main features of 


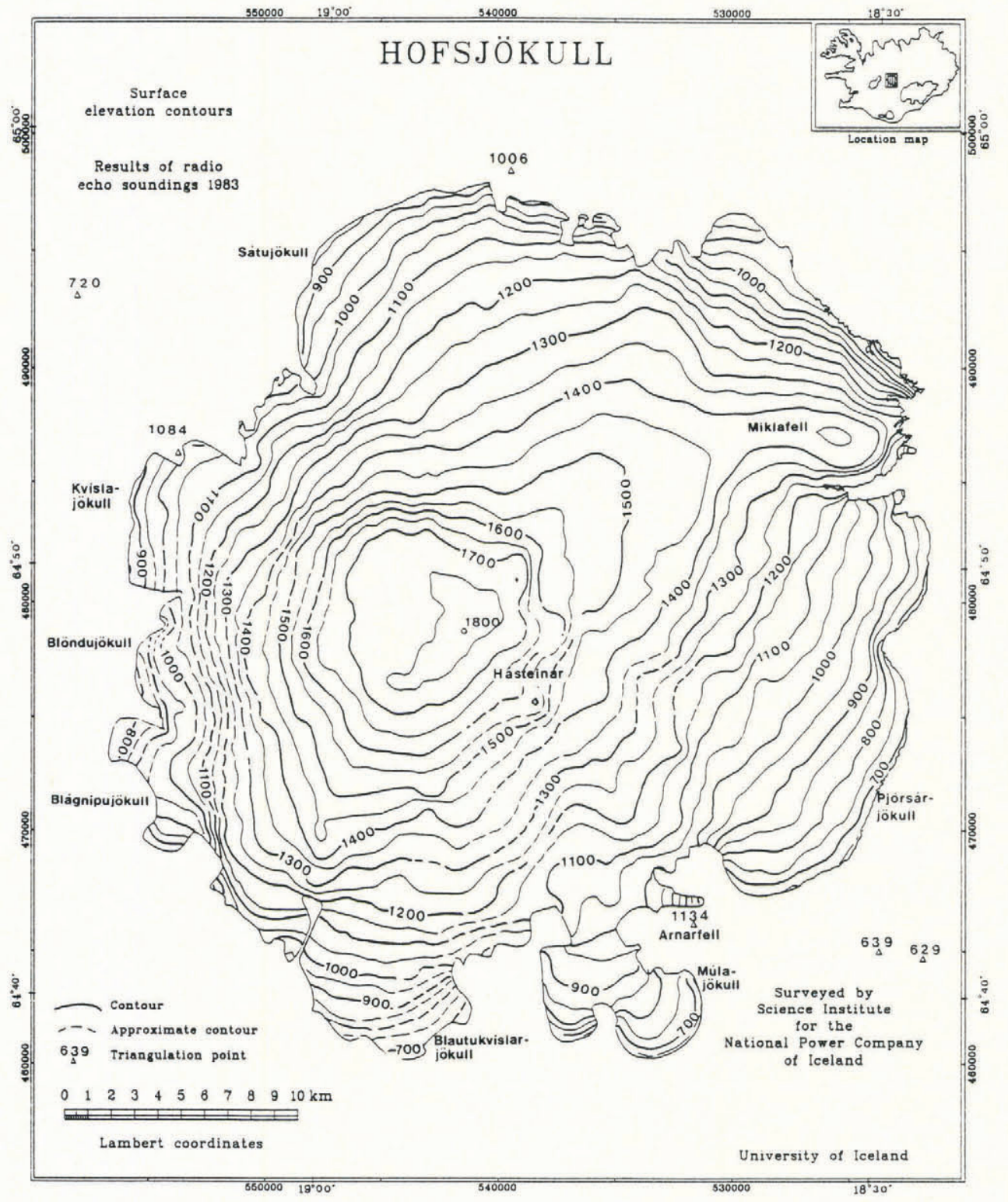

Fig.9. A map of ice-surface contours of Hofsjökull. 


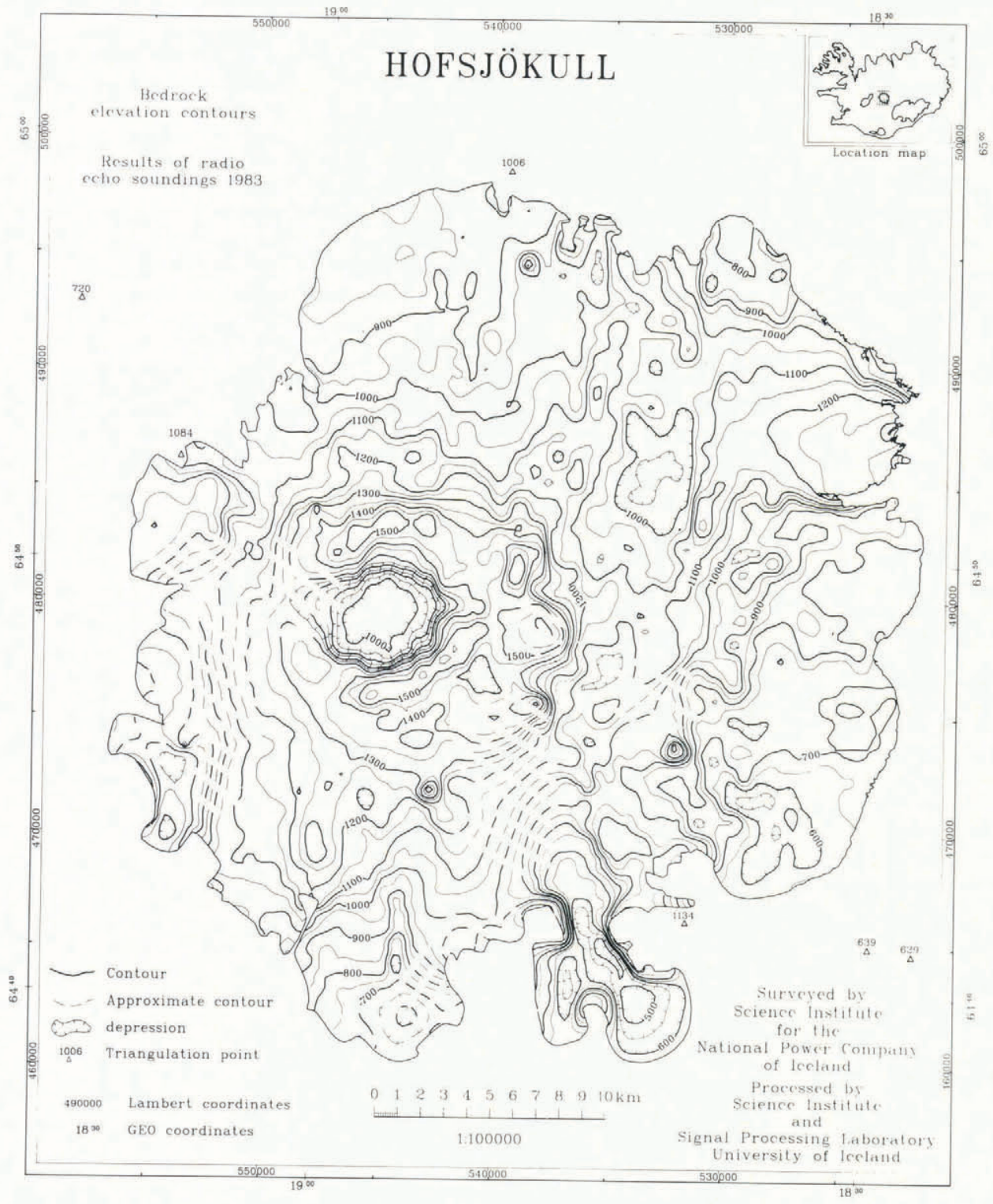

Fig.10. A map of sub-ice contours of Hofsjökjull.

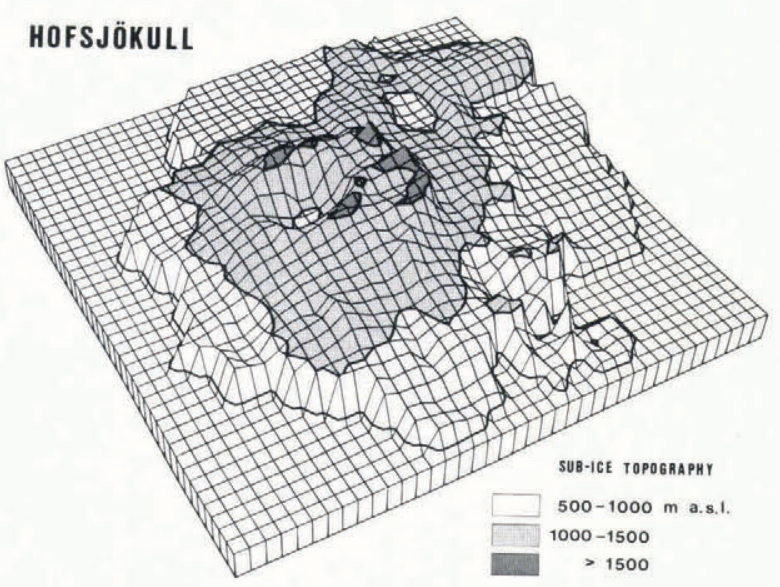

Fig.11. A three-dimensional, perspective plot of the bedrock beneath Hofsjökull.

the bedrock beneath Hofskjökull. Fig.12 shows the distribution of area and ice volume with elevation. About $2 / 3$ of the bedrock of Hofsjökull is above $1000 \mathrm{~m}$ and $1 / 9$ higher than $1300 \mathrm{~m}$. The total volume of ice on Hofsjökull is $200 \mathrm{~km}^{3}$ and the average thickness is $215 \mathrm{~m}$.

The bedrock map reveals a north to south alignment in

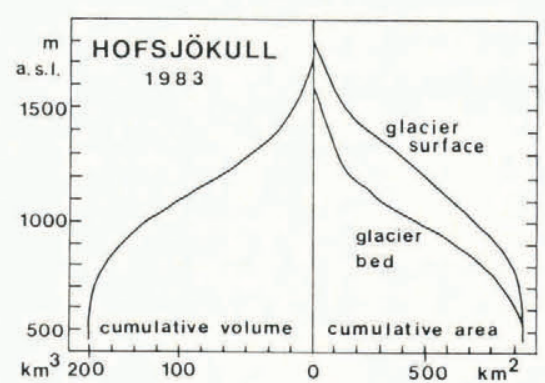

Fig.12. Area and volume distribution with elevation, for Hofsjökull.

the landscape in southern Hofsjökull. A ridge strikes southwards from the south-western corner of the central volcano and separates Blautukvislarjökull and Blágnípujökull (see Fig.9 for place names). Further east, on Thjórsárjökull, the north-south strike is seen, north of Arnarfell (see Fig.9). The peculiar, narrow north-south valley on Blautukvislarjökull may be eroded by catastrophic jökulhlaups from the central volcano. The deep north-south valley, north of Múlajökull, may be tectonically induced, as well as caused by ice and water erosion.

Beneath the deeply-eroding outlet, Múlajökull, the bottom is locally down to $500 \mathrm{~m}$ elevation, the lowest on 
Hofsjökull, which is $100 \mathrm{~m}$ lower than in front of the glacier outlets.

In northern Hofsjökull a north by $25^{\circ}$ east alignment dominates the landscape. A mountain ridge runs north-north-east from the central volcano and another parallel ridge strikes south-south-west from Miklafell. Between those ridges is a trough-formed valley, where the elevation is locally at $950 \mathrm{~m}$. The ice cap, Hofsjökull, is supported by the main, central volcano and Miklafell and the two ridges that strike out from them. Outside the caldera, the ice is thickest on the ice ridge above the valley, between the two mountain ridges $(580 \mathrm{~m})$.

\section{CONCLUSION}

The maps compiled from the precision, pressure altimetry are the first, accurate maps available of the surface elevation of the large ice caps in Iceland. They form the basis for delineation of ice-drainage basins and theoretical studies of glacier flow. The maps of the bedrock topography reveal previously unexplored landforms and geological structures within the active volcanic zone in Iceland. Together, the ice surface and the sub-ice maps are used to estimate the volume of the ice caps and its distribution as well as to define drainage basins for the rivers that run from the ice caps (Björnsson, in press).

\section{ACKNOWLEDGEMENTS}

The fieldwork on western Vatnajökull and Hofsjökull, as well as the processing of the data, was financed by the National Power Comapny of Iceland. Jón Sveinsson and Marteinn Sverrisson operated the echo-sounder and the geoceiver, in the field. Finnur Pálsson operated computers during the data processing. Tómas Jóhannesson and Magnus T. Gudmandsson worked on the data processing of Hof sjökull.

\section{REFERENCES}

Björnsson H 1974 Explanation of jökulhlaups from Grimsvötn, Vatnajökull, Iceland. Jökull 24: 1-26

Björnsson H 1977 The cause of jökulhlaups in the Skaftá river, Vatnajökull. Jökull 27: 71-78

Björnsson H 1978 Könnun á jöklum med rafsegulbylgjum. Náttúrufradingurinn 47(3-4), 1977: 184-194

Björnsson H 1981 Radio echo-sounding maps of Storglaciären, Isfallsglaciären and Rabots glaciär, northern Sweden. Geografiska Annaler 63A(3-4): 225-231

Björnsson H 1982 Drainage basins on Vatnajökull mapped by radio echo soundings. Nordic Hydrology 1982(4): 213-232

Björnsson H 1983 A natural calorimeter at Grimsvötn; an indicator of geothermal and volcanic activity. Jökull 33: $13-18$

Björnsson H 1986 Delineation of glacier drainage basins on western Vatnajökull. Annals of Glaciology 8:

Björnsson H, Kristmannsdóttir H 1984 The Grímsvötn geothermal area, Vatnajökull, Iceland. Jökull 34: 25-50

Björnsson H, Ferrari R L, Miller K J, Owen G 1977 A 1976 radio echo sounding expedition to the Vatnajökull ice cap, Iceland. Polar Record 18(115): 375-377

Eythórsson J 1951 Thykkt Vatnajökuls. Jökull 1: 1-6

Eythórsson J 1952 Landid undir Vatnajökli. Jökull 2: 1-4

Freysteinsson S 1984 Tungnárjökull-langskurdarmælingar 1959-1979. Jökull 34: 131-139

Harrison C H 1970 Reconstruction of subglacial relief from radio echo-sounding records. Geophysics 35(6): 1099-1115

Holtzscherer J-J 1954 Expédition Franco-islandaise au Vatnajökull, mars-avril 1951. Résultats des sondages seismiques. Jökull 4: 1-33

Larsen G 1984 Recent volcanic history of the Veidivötn fissure swarm, southern Iceland - an approach to volcanic risk assessment. Journal of Volcanology and Geothermal Research 22: $33-58$

Nørlund N E 1944 Islands kortlægning; en historisk fremstilling. Geodatisk Instituts Publikationer 7

Pálmason G 1964 Gravity measurements in the Grímsvötn area. Jökull 14: 61-66

Rist S 1967 The thickness of the ice cover of Myrdalsjökull, southern Iceland. Jökull 17: 237-242
Sæmundsson K 1979 Outline of the geology of Iceland. Jökull 29: 7-28

Sigurdsson S Th 1970 Gravity survey on western Vatnajökull. Jökull 20: 38-44

Simpson R J 1978 Surface II Graphics System. Kansas, KS, Kansas Geological Survey

Sverrisson M, Jóhannesson Æ, Björnsson H 1980 Radio-echo equipment for depth sounding of temperate glaciers. Journal of Glaciology 25(93): 477-486

Thorarinsson S 1974 Vötnin strid. Saga Skeidarärhlaupa og Grimsvatnagosa. Reykjavík, Bókautgafa Menningarsjóds

Thorarinsson S, Sæmundsson K, Williams R S Jr 1973 ERTS-1 image of Vatnajökull. Analysis of glaciological, structural and volcanic features. Jökull 23: 7-17 